University of Nebraska - Lincoln

DigitalCommons@University of Nebraska - Lincoln

Agronomy \& Horticulture - Faculty Publications

Agronomy and Horticulture Department

$9-16-2020$

\title{
Registration of 'NE10589' (Husker Genetics Brand Ruth) hard red winter wheat
}

\author{
P. Stephen Baenziger \\ University of Nebraska-Lincoln, pbaenziger1@unl.edu \\ Robert Graybosch \\ University of Nebraska-Lincoln, rgraybosch@gmail.com \\ Devin J. Rose \\ University of Nebraska-Lincoln, drose3@unl.edu \\ Lan Xu \\ University of Nebraska-Lincoln, Ixu4@unl.edu \\ Mary Guttieri \\ USDA, Agricultural Research Service, mary.guttieri@usda.gov
}

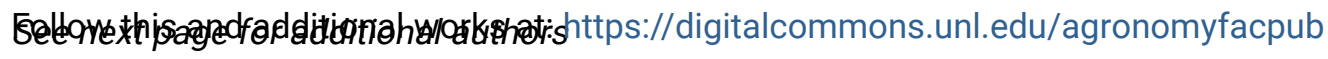

Part of the Agricultural Science Commons, Agriculture Commons, Agronomy and Crop Sciences

Commons, Botany Commons, Horticulture Commons, Other Plant Sciences Commons, and the Plant

Biology Commons

Baenziger, P. Stephen; Graybosch, Robert; Rose, Devin J.; Xu, Lan; Guttieri, Mary; Regassa, Teshome; Klein, Robert N.; Kruger, Greg R.; Santra, Dipak; Hergert, Gary; Wegulo, Stephen; Jin, Y.; Kolmer, J.; Hein, Gary; Bradshaw, Jeff; Chen, M.-S.; Bai, G.; Bowden, R. L.; El-Basyoni, Ibrahim; and Lorenz, A., "Registration of 'NE10589' (Husker Genetics Brand Ruth) hard red winter wheat" (2020). Agronomy \& Horticulture -Faculty Publications. 1426.

https://digitalcommons.unl.edu/agronomyfacpub/1426

This Article is brought to you for free and open access by the Agronomy and Horticulture Department at DigitalCommons@University of Nebraska - Lincoln. It has been accepted for inclusion in Agronomy \& Horticulture -Faculty Publications by an authorized administrator of DigitalCommons@University of Nebraska - Lincoln. 


\section{Authors}

P. Stephen Baenziger, Robert Graybosch, Devin J. Rose, Lan Xu, Mary Guttieri, Teshome Regassa, Robert N. Klein, Greg R. Kruger, Dipak Santra, Gary Hergert, Stephen Wegulo, Y. Jin, J. Kolmer, Gary Hein, Jeff Bradshaw, M.-S. Chen, G. Bai, R. L. Bowden, Ibrahim El-Basyoni, and A. Lorenz 
Cultivar

\title{
Registration of 'NE10589' (Husker Genetics Brand Ruth) hard red winter wheat
}

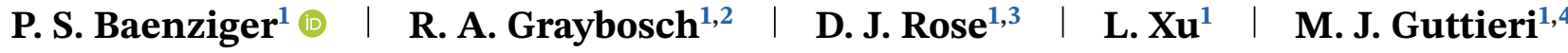

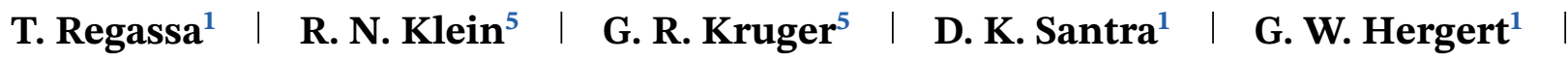

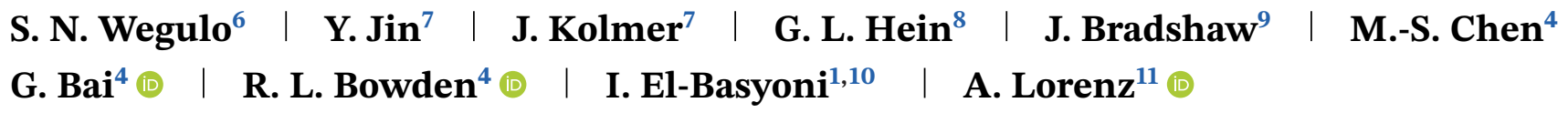

${ }^{1}$ Dep. of Agronomy and Horticulture, Univ. of Nebraska, Lincoln, NE 68583

${ }^{2}$ USDA-ARS, Wheat, Sorghum and Forage Research Unit, Lincoln, NE 68583, USA

${ }^{3}$ Dep. of Food Science and

Technology, Univ. of Nebraska, Lincoln, NE 68583, USA

${ }^{4}$ Current address: USDA-ARS, Hard Winter Wheat Genetics Research Unit, Manhattan, KS 66506, USA

${ }^{5}$ Dep. of Agronomy and Horticulture, West Central Research and Extension Center, North Platte, NE 69101, USA

${ }^{6}$ Dep. of Plant Pathology, Univ. of Nebraska, Lincoln, NE 68583

${ }^{7}$ USDA-ARS, Cereal Disease Lab., St. Paul, MN 55108

${ }^{8}$ Dep. of Entomology, Univ. of Nebraska, Lincoln, NE 68583

${ }^{9}$ Dep. of Entomology and Panhandle Research and Extension Center, Scottsbluff, NE 69361, USA

\begin{abstract}
With climate variation common in the U.S. Great Plains and particularly in Nebraska, wheat growers prefer broadly adapted cultivars. 'NE10589' (Reg. no. CV-1165, PI 675998) hard red winter wheat (Triticum aestivum L.) was developed cooperatively by the Nebraska Agricultural Experiment Station and the USDAARS and released in January 2015 by the developing institutions. NE10589 was released primarily as a broadly adapted semi-dwarf cultivar for its superior performance under rainfed conditions throughout Nebraska and adjacent areas of the Great Plains. Its broad adaptation ensures that it will perform well under the typical environmental fluctuations that occur in Nebraska. NE10589 was selected from the cross 'OK98697'/'Jagalene'//'Camelot', where the pedigree of OK98697 is 'TAM 200'/'HBB313E'//'2158'. The $\mathrm{F}_{2}$ to $\mathrm{F}_{3}$ generations were advanced using the bulk breeding method at the Eastern Nebraska Research and Extension Center near Mead, NE, in 2006-2007. In 2007-2008, single $F_{3: 4}$ head rows were grown for selection. There was no further selection within the line thereafter. The $F_{3: 5}$ was evaluated as a single four-row plot at Lincoln, NE, and a single row at Mead, NE, in 2009. In 2010, it was assigned the experimental line number NE10589. NE10589 was evaluated in replicated trials thereafter. It has excellent winter
\end{abstract}




\footnotetext{
${ }^{10}$ Current address: Faculty of Agriculture, Damanhour Univ., Damanhour 22511, Egypt

${ }^{11}$ Dep. of Agronomy and Plant Genetics, Univ. of Minnesota, St. Paul, MN 55108, USA

\section{Correspondence}

P.S. Baenziger, Dep. of Agronomy and Horticulture, Univ. of Nebraska, Lincoln, NE 68583, USA.

Email:pbaenziger1@unl.edu

Funding information

CSREES NRICAP, Grant/Award Number: 2007-51300-03785; Nebraska Wheat

Development, Utilization, and Marketing Board; U.S. Wheat \& Barley Scab Initiative, Grant/Award Number: 59-0790-4-092; USDA, NRICGP, Grant/Award Numbers: 00-353000-9266, 2004-35300-1470, 200751300-03; USDA-IFAFS, Grant/Award Number: 2001-04462; USDA AFRI, Grant/Award Number: 2011-68002-30029; USDA OREI, Grant/Award Number: 2007-51300-03785; Hatch Project, Grant/Award Number: NEB-22-328; CERES Trust Organic Research Initiative Registration by CSSA.
}

survival, acceptable disease reactions to many of the common diseases in its target area, and acceptable end-use quality for bread making.

\section{1 | INTRODUCTION}

Nebraska is climatically and geographically diverse (Peterson, 1992), with an annual moisture gradient from higher moisture in eastern Nebraska to lower moisture in western Nebraska. Similarly, there are temperature and elevation gradients across the state. Due to temporal and spatial rainfall and temperature variations, wheat (Triticum aestivum L.) cultivars with broad adaptation are preferred by wheat producers who understand environmental fluctuations and want cultivars that can be grown in wet or dry, hot or cool years, which are unknown and unpredictable at the time of selecting a cultivar and planting. Popular previous wheat cultivars with broad adaptation included 'Arapahoe' (Baenziger et al., 1989), 'Millennium' (Baenziger et al., 2001), 'NE01643' (Husker Genetics Brand Overland; Baenziger et al., 2008), 'NI04421' (Husker Genetics Brand Robidoux; Baenziger et al., 2012a), and 'NE06545' (Husker Genetics Brand Freeman; Baenziger et al., 2014). All five cultivars are semi-dwarf lines. Providing higher yielding, semi-dwarf wheat cultivars remains a goal of the Nebraska Agricultural Experiment Station and the USDAARS cooperative wheat improvement team. Other major goals of the Nebraska wheat improvement team include the ability to survive the Nebraska winter, resistance to stem rust (caused by Puccinia graminis Pers.:Pers. f. sp. tritici Eriks \& E. Henn.), and the capability of producing an acceptable loaf of bread (Baenziger, Shelton, Shipman, \& Graybosch, 2001).

'NE10589' (Reg. no. CV-1165, PI 675998) hard red winter wheat was tested under experimental line designation NE10589 and was developed and released in January 2015 cooperatively by the Nebraska Agricultural Experiment Station and the USDA-ARS. It was released primarily for its superior adaptation to rainfed wheat production systems throughout Nebraska and in adjacent wheatproducing states. In addition, it has consistently survived the Nebraska winter, shown good stem rust resistance, and good end-use quality. NE10589 will be marketed as Husker Genetics Brand Ruth hard red winter wheat. It was named in honor of our greenhouse manager, who was a huge aid to the breeding program and who died far too young.

\section{2 | METHODS}

\section{1 | Selection history}

NE10589 was selected from the cross OK98697/'Jagalene'// 'Camelot' (Baenziger et al., 2009), where the pedigree of 
OK98697 is 'TAM 200' (PI 579255)/'HBB313E'//'2158' (PI 601723). The final cross was made in 2004. The $F_{1}$ generation was grown in Yuma, AZ, in 2004-2005. The $F_{2}$ to $\mathrm{F}_{3}$ generations were advanced using the bulk breeding method in the field at the University of Nebraska Eastern Nebraska Research and Extension Center (formerly the Agricultural Research Development Center) near Mead, NE (hereafter referred to as Mead) in 2005-2006 to 20062007. Each $\mathrm{F}_{2}$ bulk was planted in a 2.4-m-long fourrow plot with $30 \mathrm{~cm}$ between rows at a seeding rate of $66 \mathrm{~kg} \mathrm{ha}^{-1}$. After a mild selection among crosses of $<15 \%$ to remove very poor bulks, based upon poor winter survival, disease susceptibility, extreme lateness, or lodging, $\mathrm{F}_{3}$ bulks were planted in September 2006 in an unreplicated $\mathrm{F}_{3}$ bulk nursery, each as a 5-m-long four-row plot with $30 \mathrm{~cm}$ between rows. Approximately $40 \%$ of the $\mathrm{F}_{3}$ populations was visually selected on an estimate of winter survival, disease resistance, and general agronomic appearance based mainly on plant height, flowering date, straw strength, and visually estimated yield potential. Each selected population was advanced by randomly sampling approximately 100 spikes (synonym heads) in July 2007, although especially meritorious bulks had a sample of 200 to 300 spikes selected. For the $\mathrm{F}_{3}$ population from which NE10589 was selected, 100 spikes were selected. Selected spikes were threshed individually and planted in a headrow nursery in September 2007 at Lincoln, NE. Each headrow selection was planted as a single $0.9-\mathrm{m}$ row with $30 \mathrm{~cm}$ between rows using a four-row drill in a four-row set. Four different head rows were planted in the set. A total of seven head rows were selected from the population from which NE10589 was derived. Seed from the selected head rows was harvested. In fall 2008, NE10589 was planted in a rainfed nursery at Mead as a single row $3 \mathrm{~m}$ long to measure winter survival and at Lincoln, NE, in a single 2.4-m-long four-row plot with $30 \mathrm{~cm}$ between rows. An unreplicated nursery with replicated check cultivars design was used. Selection in July 2009 was based upon the line surviving the winter, being resistant to stem rust, having agronomic merit (standability, grain yield, grain volume weight, maturity), and having acceptable end-use quality (Baenziger et al., 2001). Two lines from this population were selected for advancement. In fall 2009, NE10589 was planted as the entry 589 (where entries ranged from 401 to 700 and were stratified by flowering date) of the Nebraska preliminary yield trial at 10 environments (Mead [conventional and organic], Lincoln, Clay Center, McCook, North Platte, Sidney [conventional and organic], Alliance, and one in south-central Kansas) in an unreplicated nursery with replicated check cultivars. The experimental name was chosen as the last two digits of the year it was entered and the entry number for the preliminary yield trial. Based upon its performance in the preliminary yield trial, it was entered in the advanced yield trial using an incomplete block design with incomplete blocks of five entries nested in three blocks of 60 entries grown at Mead (conventional and organic), Lincoln, Clay Center, McCook, North Platte, Sidney (conventional and organic), and Alliance in 2011. In 2012, it was advanced to the elite yield trial using an incomplete block design with incomplete blocks of five entries nested in blocks of 60 entries and grown at 11 environments in Nebraska and Kansas (Mead [unsprayed and sprayed with fungicide], Lincoln [unsprayed and sprayed with fungicide], Clay Center, North Platte, McCook, Sidney, Alliance, and one in south-central Kansas), where it continued to be tested until its release.

The fungicide-sprayed plots were sprayed at flag leaf (GS 39) with Twinline ([2-[[[1-(4-chloropheny)-1Hpyrazol-3-yl]oxy]methyl]phenyl]methoxy-, methyl ester), metconazole, 5-[(4-chlorophenyl)methyl]-2,2-dimethyl-1(1H-1,2,4-triazol-1-ylmethyl) cyclopentanol, BASF Corporation) at the recommended $657 \mathrm{ml} \mathrm{ha}^{-1}$. At the flowering growth stage (GS 61) the fungicide-sprayed plots were sprayed with Caramba (5-[(4-chlorophenyl)methyl]-2,2dimethyl-1-(1H-1,2,4-triazol-1-ylmethyl) cyclopentanol, BASF Corporation) at the recommended rate of $1170 \mathrm{ml}$ $\mathrm{ha}^{-1}$ to suppress Fusarium head blight (caused by Fusarium graminearum Schwabe; Andersen, Morris, Derksen, Madden, \& Paul, 2014). At Lincoln and Mead, the trials had two blocks sprayed with fungicide (as described above) and two blocks that were not treated with fungicides. The trials had two blocks at McCook and three blocks at the remaining locations. Once NE10589 was identified in 2010, the only selection thereafter was rogueing to remove obvious off-types (usually plants that were taller than the majority of plants, awnless, or had bronze chaff). This line seems to be very broadly adapted and was selected using phenotypic, diversity, and the genomic estimated breeding value (GEBV) (El-Basyoni et al., 2013; Endelman \& Jannink, 2012). The GEBV was estimated using a ridge regression best linear unbiased prediction model implemented using the R package $\operatorname{rrBLUP}$ (Endelman \& Jannink, 2012) in which the previous season's phenotypic data were used as a training population.

NE10589 was entered into the USDA-ARS coordinated Northern Regional Performance Nursery (NRPN) in 2013 and 2014, the Southern Regional Performance Nursery (SRPN) in 2014 (data at http://www.ars.usda. gov/Research/docs.htm?docid=11932) and in the Nebraska State Variety Trial (NESVT) from 2014-2015 (data available at http://cropwatch.unl.edu/web/varietytest/wheat). The NESVT was planted at 13 to 15 rainfed and one to three irrigated locations with three to six replications in Nebraska or combined with nearby locations 
in Wyoming. Normally one to three locations were lost each year due to hail, freeze, drought, or severe disease incidence.

Lines were advanced based upon winter survival (determined at Mead, NE), resistance to stem rust and other foliar diseases prevalent in the field, uniformity, and general agronomic appearance. General agronomic appearance included plant height measured from the soil surface to the tip of the spikes, excluding the awns; flowering date measured as the number of days after 1 January to when $50 \%$ of the emerged spikes had extruded anthers, straw strength measured using a scale of $1-10$, with 1 being little to $10 \%$ lodging and 10 being $100 \%$ lodged; grain yield; and grain volume weight. Experimental wheat lines were compared with relevant released cultivars and experimental lines for their targeted region for advancement (e.g., semi-dwarf wheat lines were compared with other semi-dwarf cultivars [historically the highest grain yielding types in Nebraska], tall wheat lines were compared with other tall cultivars, herbicide-tolerant wheat lines were compared with other herbicide-tolerant cultivars, and white- or red-seeded wheat lines were compared with other white- or red-seeded cultivars, respectively). Selections were also based on three main ecological zones (eastern and south-central Nebraska, west-central and southwestern Nebraska, and the Panhandle; Peterson, 1992). Lines that did well in all three ecological zones were considered broadly adapted, while lines that did well in one or two ecological zone are considered more narrowly adapted. In addition to our phenotypic selection, lines with superior GEBVs (Endelman \& Jannink, 2012) were selected with a priority given to lines selected by both phenotype and GEBV.

\section{2 | Disease and insect evaluation}

During the winter, lines in the preliminary observation, preliminary, advanced, and elite yield trails were evaluated in the greenhouse in Lincoln, NE, for their resistance to stem rust using race TPMKC or QFCSC (Sidiqi, Wegulo, Read, \& Baenziger, 2009) and at the USDA-ARS Cereal Disease Laboratory using races QFCSC, QTHJC, MCCFC, RCRSC, RKQQC, TPMKC, and TTTTF in the greenhouse and a composite of races QFCSC, QTHJC, RCRSC, RKQQC, and TPMKC in the field at St. Paul, MN, for the advanced yield trial and regional performance nurseries (Rouse, Wanyera, Njau, \& Jin, 2011). In addition, lines in the preliminary, advanced, and elite yield trails were evaluated in the greenhouse at Lincoln and in the regional trials at the Cereal Disease Laboratory for leaf rust (caused by $P$. triticina Eriks; Watkins, Schimelfenig,
Baenziger, \& Eskrdige, 2001; Kolmer, 2003), and in the field (data from the regional performance nurseries using naturally occurring isolates) for leaf rust and stripe rust (caused by $P$. striiformis Westendorp f. sp. tritici). For Wheat soilborne mosaic virus, the lines were screened in the field at Lincoln and in the regional performance nurseries using naturally occurring strains (Hunger, Armitage, \& Sherwood, 1989). NE10589 was screened for its reaction to Wheat streak mosaic virus (and possibly Triticum mosaic virus and High Plains wheat mosaic virus) by using a field screen that involved exposure to virus through natural fall infestations of wheat curl mites during 2015-2016 and 2016-2017.

Lines in the elite yield trial were evaluated in the greenhouse for Fusarium head blight. Each spike was artificially inoculated with a spore suspension of an isolate of $F$. graminearum at $1 \times 10^{5}$ spores $\mathrm{ml}^{-1}$ at mid-anthesis using a handheld bottle sprayer. To obtain the spore suspension, an isolate of $F$. graminearum obtained from a Nebraska wheat field was grown on potato dextrose agar plates on a laboratory bench for $3 \mathrm{wk}$. Sterile distilled water $(5 \mathrm{ml})$ was added to each plate, and a rubber policeman was used to dislodge spores. The spore suspension was filtered through two layers of cheesecloth into a beaker, and the concentration was adjusted to $1 \times 10^{5}$ spores $\mathrm{ml}^{-1}$ with distilled water. Approximately $2 \mathrm{ml}$ of the spore suspension was applied to each spike with a handheld bottle sprayer, and the spike was then covered with a transparent plastic bag for $3 \mathrm{~d}$ following inoculation. The FHB severity (\%) was visually estimated $14 \mathrm{~d}$ after inoculation. In the field, natural infection, inoculated without irrigation, and inoculated with mist irrigation nurseries were used to evaluate the lines (Wegulo et al., 2011). Lines in the elite yield trial were also evaluated for their resistance to Hessian fly (Mayetiola destructor Say; Great Plains biotype) by the USDA-ARS Hard Winter Wheat Genetics Research Unit (Chen et al., 2009).

\section{3 | End-use quality evaluation}

For end-use quality, the preliminary lines were evaluated using a Mixograph (National Manufacturing) and for protein concentration (Baenziger et al., 2001). The advanced lines were evaluated using composited grain samples from western Nebraska (locations other than Lincoln or Mead that were harvested for seed). Bread baking properties were evaluated by approved methods of the American Association of Cereal Chemists (2000). Bake mixing time, water absorption, external and internal grain and texture were recorded (American Association of Cereal Chemists, 2000; Baenziger et al., 2001, 2008). 


\subsection{Statistical analyses}

The elite and advanced breeding trials were analyzed annually using an incomplete block design within blocks (using Agrobase GEN II, Agronomix Software; Stroup, Baenziger, \& Mulitze, 1994). Occasionally, advanced and elite trials with three or more blocks were analyzed using the nearest neighbor analysis procedure of Agrobase GEN II (Stroup et al., 1994). Because Nebraska has three major wheat-producing regions (Peterson, 1992) and our irrigated trials are considered environmentally different from the rainfed trials, data were analyzed within a location or an irrigation treatment (irrigated or rainfed). Location means and ranks were examined, and lines were selected by having excellent performance within a location or irrigation treatment, across locations within a region, and at all locations or irrigation treatments within a year based on the arithmetic mean of the adjusted means, or across locations, irrigation treatments, and years based on the arithmetic mean of the adjusted means. A truncated selection procedure was used as a risk avoidance strategy. Basically, if a line did well in 1 or $2 \mathrm{yr}$ and then poorly in the next year, the line was discontinued because it might perform poorly in a producer's field. For summary data, however, we used the head-to-head cultivar (synonym variety) comparison of Agrobase GEN II, which allowed us to compare lines from different sets of trials with each other. Analyses of the NRPN and SRPN data used SAS (SAS Institute) for a randomized complete block design within locations and across locations within a year. Entries tested in the NRPN were statistically analyzed only within years due to many entries being tested for only 1 yr. For the NESVT, the trials were analyzed using the SAS Mixed Model for a randomized complete block design with a row and column repeated statement with SP[POWA] in order to account for possible spatial effects within the block randomization restrictions. For NE10589, the data from the rainfed trials (2014 and 2015) were used for advancement and release. The NESVT had different entries in each region, so all of the entries were analyzed using randomized complete block designs unless a spatial correction was needed as a group and data were reported by region. No across-region analyses were done.

\section{3 | CHARACTERISTICS}

\section{1 | Agronomic and botanical description}

The coleoptile color of NE10589 is white and the juvenile growth habit is prostrate. NE10589 is an awned, tanglumed cultivar. Its field appearance is most similar to
'Wesley' but can be easily separated from Wesley because Wesley has bronze chaff. After heading, the canopy is moderately closed and erect to inclined. The flag leaf is recurved and twisted at the boot stage. The foliage is green with a waxy bloom on the leaf sheath, with little waxy bloom on the spike at anthesis and on the leaves. The leaves are glaborous. The spike is tapering, narrow, and lax. The glume is short and wide, and the glume shoulder is square to elevated. The beak has an acuminate tip. The spike is predominantly inclined at maturity with some recurved spikes. Kernels are red colored, hard textured, and mainly ovate in shape. The kernel has no collar, a medium brush of short length, rounded cheeks, midsize germ, and a narrow and shallow crease.

While considerable data are available from the breeding nurseries during line development, the majority of the data presented here are from the head-to-head cultivar comparison for grain yield from the Nebraska elite trial (Table 1), the NRPN, and NESVT (Table 2) as the latter two have their complete reports readily available (http: //www.ars.usda.gov/Research/docs.htm?docid=11932 and http://varietytest.unl.edu/winterwheat.html, respectively). For grain yield in Nebraska (Table 1), NE10589 was significantly higher yielding than Camelot, 'Goodstreak' (Baenziger et al., 2004), 'NE01481' (Husker Genetics Brand McGill, Baenziger et al., 2012b), 'NE05548' (Husker Genetics Brand Panhandle; Baenziger et al., 2016), Freeman, Robidoux, Overland, 'NH03614 CL' (Husker Genetics Brand Settler CL, Baenziger et al., 2011), and Wesley (Peterson et al., 2001). Of these lines, only Goodstreak was a taller wheat and the rest were popular semi-dwarf cultivars at the time of release, hence the logical cultivars for comparison. Freeman and Robidoux would be considered as broadly adapted, hence so was NE10589. These data are supported by the 2013 and 2014 USDA-ARS NRPN and 2014 USDA-ARS SRPN, where NE10589 ranked ninth, second, and 19th, respectively, of the 37, 40, and 40 entries tested regionwide in those years (data available at http:// www.ars.usda.gov/Research/docs.htm?docid=11932).

In the $2 \mathrm{yr}$ that it was tested in the NESVT across 25 environments (Table 2), NE10589 (3436 kg ha-1) was higher yielding than Freeman (3214 $\left.\mathrm{kg} \mathrm{ha}^{-1}\right)$, 'Mattern' (PI 665947; $2988 \mathrm{~kg} \mathrm{ha}^{-1}$; Graybosch et al., 2014), Overland $\left(3275 \mathrm{~kg} \mathrm{ha}^{-1}\right)$ and Wesley $\left(2947 \mathrm{~kg} \mathrm{ha}^{-1}\right)$ as well as the long-term check cultivars 'Scout 66' (Schmidt, Johnson, Mattern, \& Drier, 1971; $2520 \mathrm{~kg} \mathrm{ha}^{-1}$ ) and 'Turkey' (2512 kg $\left.\mathrm{ha}^{-1}\right)$. NE10589 is adapted to rainfed wheat production in all ecological zones of Nebraska and a very competitive semi-dwarf wheat. Using data from the NESVT, NE10589 would be considered a taller semi-dwarf wheat cultivar similar to Overland. Molecular marker data indicate that NE10589 carries the RhtB1b (Rht1) allele for reduced plant height. NE10589 has a grain volume weight and 
TA B L E 1 Head-to-head comparisons of NE10589 with nine popularly grown or new cultivars from trials in Nebraska beginning in 2012 until 2015. Data on grain yield, grain volume weight, and plant height were from trials at up to eight rainfed locations (Mead, Lincoln, Clay Center, North Platte, McCook, Grant, Sidney, and Alliance) in Nebraska in each year (total environments in the comparison is $N$ ) and not every cultivar was grown in the same trial across the state

\begin{tabular}{|c|c|c|c|c|c|c|c|c|c|}
\hline \multirow[b]{2}{*}{ Line } & \multicolumn{3}{|c|}{ Grain yield } & \multicolumn{3}{|c|}{ Grain volume weight } & \multicolumn{3}{|c|}{ Height } \\
\hline & $\bar{N}$ & Line & NE10589 & $\bar{N}$ & Line & NE10589 & $\bar{N}$ & Line & NE10589 \\
\hline & & \multicolumn{2}{|c|}{$\mathrm{kg} \mathrm{ha}^{-1}$} & & \multicolumn{2}{|c|}{$\mathrm{kg} \mathrm{hl}^{-1}$} & & \multicolumn{2}{|c|}{$\mathrm{cm}$} \\
\hline Goodstreak & 31 & 3,374 & $3,950^{* *}$ & 14 & 73.0 & $73.2 \mathrm{~ns}$ & 24 & 104.0 & $90.7^{* *}$ \\
\hline McGill & 17 & 4,074 & $4,431^{* *}$ & 8 & 76.0 & $77.4 \mathrm{~ns}$ & 13 & 92.8 & $88.7^{* *}$ \\
\hline Robidoux & 26 & 3,639 & $3,885^{* *}$ & 10 & 76.6 & $76.1 \mathrm{~ns}$ & 20 & 90.9 & $90.9^{* *}$ \\
\hline Overland & 31 & 3,706 & $3,950^{* *}$ & 14 & 73.8 & $73.2 \mathrm{~ns}$ & 24 & 93.0 & $90.7^{* *}$ \\
\hline Settler CL & 26 & 3,339 & $3,885^{* *}$ & 10 & 76.9 & $76.1 \mathrm{~ns}$ & 20 & 85.7 & $90.9^{* *}$ \\
\hline Wesley & 31 & 3,325 & $3,950^{* *}$ & 14 & 71.6 & $73.2^{* *}$ & 24 & 85.2 & $90.7^{* *}$ \\
\hline
\end{tabular}

${ }^{* *}$ Significantly different at the $p=.01$ probability level; ns, not significantly different at the $p=.01$ probability level.

TA B L E 2 Grain yield by region and averaged across the state, and state average for grain volume weight, grain protein content, and plant height for Nebraska from 2014 to 2015 representing 25 location-years of data from rainfed environments in the Nebraska State Variety Trial

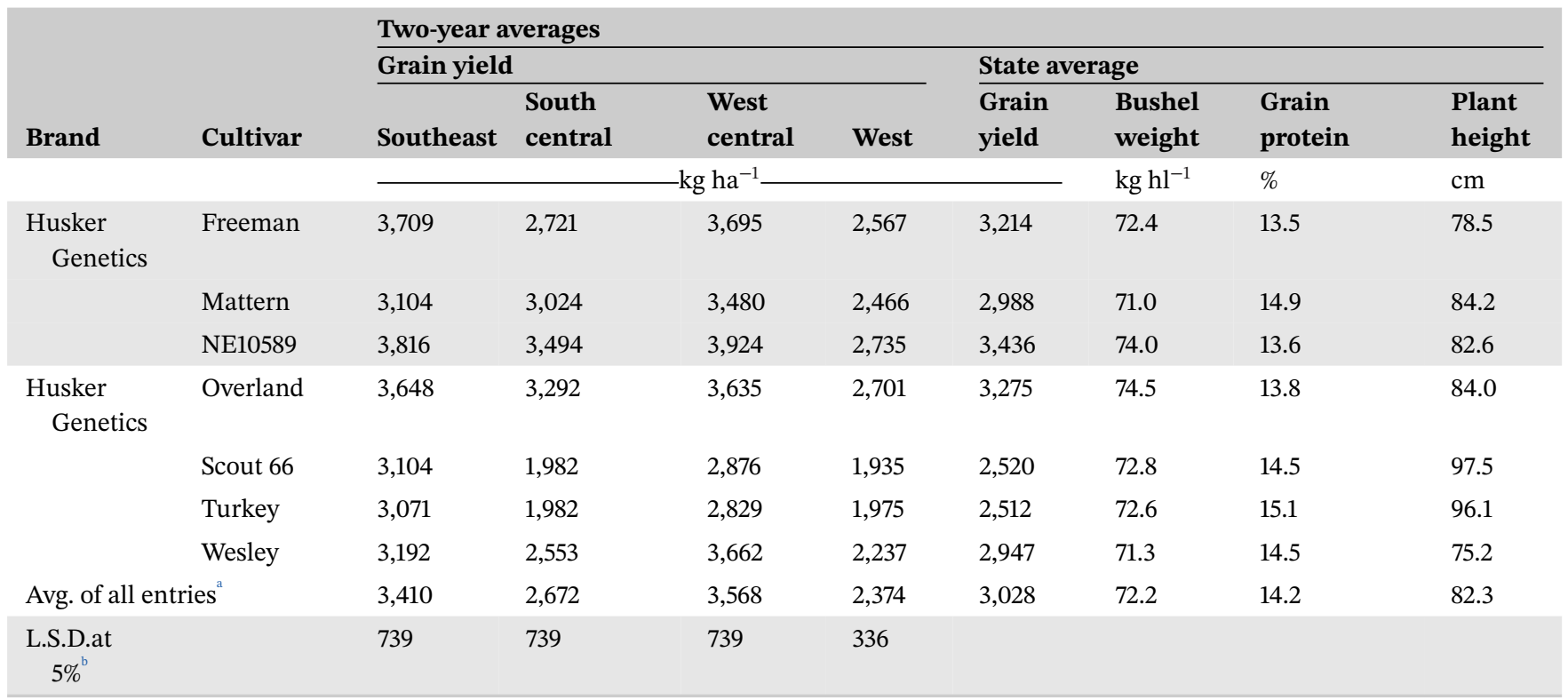

${ }^{\mathrm{a}}$ This value is the average of all the values for the traits for the entries that were in the trial and includes values for many experimental lines not shown here.

${ }^{b}$ The LSD (least significant difference $p<.05$ ) was calculated from the analysis of variance using all of the values of the entries that were in the trial including many experimental lines not shown here.

grain protein concentration that is considered good and comparable to most higher grain volume weight wheat cultivars grown in Nebraska (Table 2).

\section{2 | Disease and insect resistance}

Using data predominantly from the 2014 SRPN and 2013 and 2014 NRPN, NE10589 is resistant to Wheat soilborne mosaic virus. It is resistant to highly resistant to stem rust in field nursery tests inoculated with a composite of stem rust races (QFCSC, QTHJC, RCRSC, RKQQC, and TPMKC) at St. Paul, MN (Table 3). It was susceptible to stem rust in Njoro, Kenya (where race TTKST predominates). In greenhouse seedling tests, it is resistant or heterogeneous to races QFCSC, QTHJC, MCCFC, RCRSC, RKQQC, TMPKC, GRMNC, and QCCSM but susceptible to race TTKSK (data provided by Y. Jin at the USDA Cereal 
TA B L E 3 Seedling stem rust reaction scores of NE05548 hard red winter wheat and other check cultivars evaluated in the 2008 and 2009 Northern Regional Performance Nursery at the USDA-ARS Cereal Disease Laboratory, St. Paul, MN, or Kenya

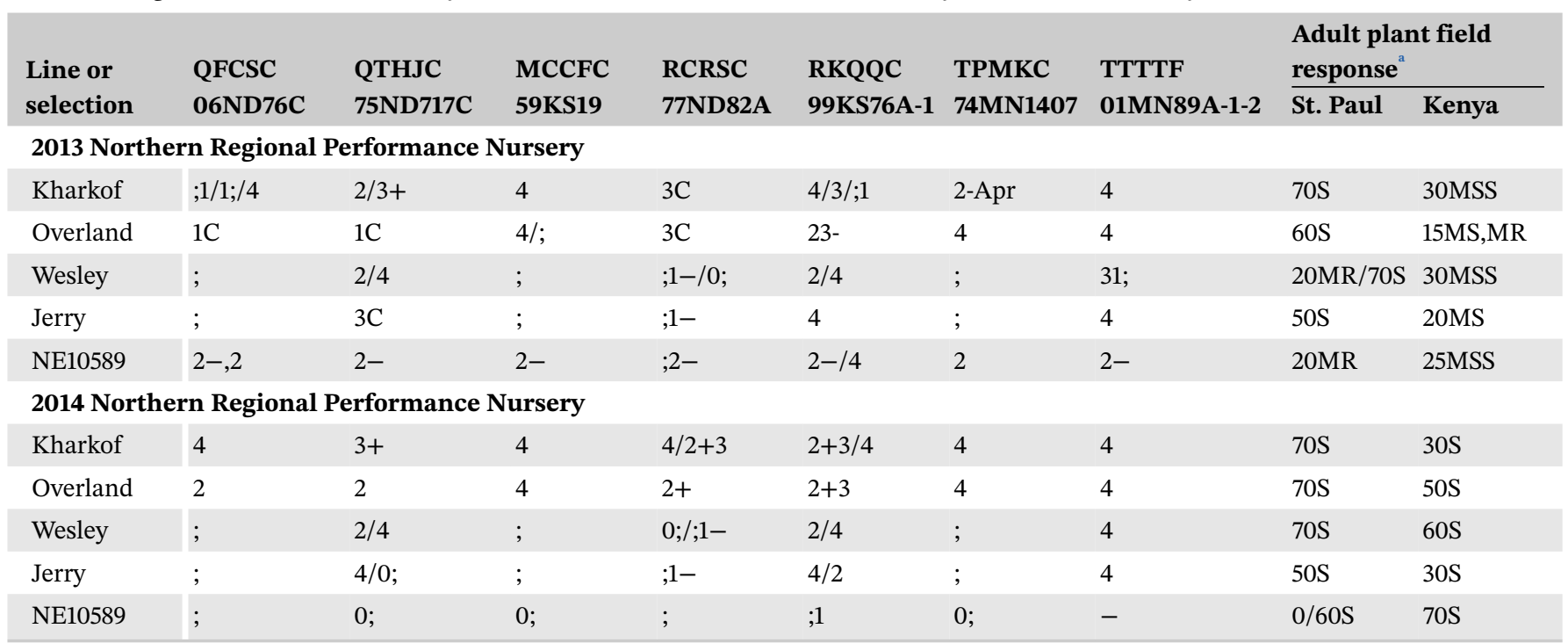

Note. Complete data set can be found at http://www.ars.usda.gov/Research/docs.htm?docid=11932. Seedling infection type: 0 , immune response, no sign of infection, 1 , small uredinia surrounded by necrosis; 2 , small uredinia surrounded by chlorosis; 3 , moderate size uredinia without necrosis or chlorosis; 4 , large uredinia without necrosis or chlorosis; +, uredinia larger than normal; -, uredinia smaller than normal; semicolon (;), hypersensitive chlorotic or necrotic flecks; S, seedlings with scores of 3 or higher.

adult plant infection response evaluation from a field stem rust nursery at St. Paul, MN, inoculated with a composite of races QFCSC, QTHJC, RCRSC, RKQQC, MCCFC, and TPMKC, and from Njoro, Kenya, with race TTKST being predominant: R, resistant; MR, moderately resistant; MS, moderately susceptible; and S, susceptible.

Disease Laboratory). NE10589 has the molecular marker indicative of $\mathrm{Lr37} / \mathrm{Sr} 38 / \mathrm{Yr} 17$. It was moderately susceptible to susceptible (20-40 moderately susceptible [MS] in 2013 and 60 susceptible [S] in 2014 at Castroville, TX) to leaf rust races of the Great Plains. Based on molecular marker information, NE10589 did not inherit the Sr24/Lr24 resistance present in Jagalene. NE10589 is expected to be resistant to Wheat soilborne mosaic virus based on an associated single nucleotide polymorphism assay. NE10589 also is positive for the marker associated with the 'Pavon' (PI 520003) allele of $L r 46 / Y r 29 / P m 39 / S r 58$. The field reaction to stripe rust is generally moderately resistant. It is moderately susceptible to Fusarium head blight (data from greenhouse and field observations in Nebraska and Kansas and moderately susceptible to deoxynivalenol accumulation). NE10589 is moderately resistant to moderately susceptible to Hessian fly (Great Plains biotype, data provided by M.-S. Chen, USDA and Kansas State University). In different tests it was classified as a resistant line (13 resistant plants and two susceptible plants, NRPN 2014) and as a moderately susceptible line with two resistant plants out of 24 plants tested for Hessian fly resistance. It is susceptible to Wheat streak mosaic virus (data obtained from field screens in Nebraska) and the wheat stem sawfly (Cephus cinctus Norton; data from western Nebraska).

\section{3 | End-use quality}

The milling and baking properties of NE10589 were determined for $4 \mathrm{yr}$ by the Nebraska Wheat Quality Laboratory (Table 4). In these tests, Wesley, an excellent milling and baking wheat, and Overland, a lower quality milling and baking wheat, were used for comparison. The average flour protein concentration of NE10589 (116 g protein $\mathrm{kg}^{-1}$ flour) was similar to Overland (114 $\mathrm{g}$ protein $\mathrm{kg}^{-1}$ flour) but lower than Wesley (131 g protein $\mathrm{kg}^{-1}$ flour) for the corresponding years (similar to results from the NESVT, Table 2). The average flour extraction on a Buhler Laboratory Mill for

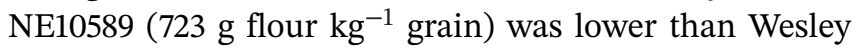
(734\% $\mathrm{g}$ flour $\mathrm{kg}^{-1}$ grain) and higher than Overland (701 $\mathrm{g}$ flour $\mathrm{kg}^{-1}$ grain). The flour ash content $\left(4.26 \mathrm{~g} \mathrm{~kg}^{-1}\right.$ flour) was higher than Wesley ( $4.09 \mathrm{~g} \mathrm{~kg}^{-1}$ flour), and similar to Overland (4.30 $\mathrm{g} \mathrm{kg}^{-1}$ flour). Dough mixing properties of NE10589 were good (mixtime peak was 4.72 min and mixtime tolerance was scored as 4.3 on a 1-7 scale, where 7 is very tolerant) and similar to Wesley (mixtime peak of $4.88 \mathrm{~min}$ and mixtime tolerance scored as 5.0). Both lines were superior to Overland (mixtime peak of $3.53 \mathrm{~min}$ and mixtime tolerance scored as 3.40). Average Mixograph absorption (635 $\mathrm{g} \mathrm{H}_{2} \mathrm{O} \mathrm{kg}{ }^{-1}$ flour) was similar to Overland (636 $\mathrm{g} \mathrm{H}_{2} \mathrm{O} \mathrm{kg}{ }^{-1}$ flour) and less than Wesley (650 g $\mathrm{H}_{2} \mathrm{O} \mathrm{kg}^{-1}$ flour) for the corresponding years. The average 
TA B L E 4 Comparison of NE10589 with Wesley and Overland from 2011 to 2014 for flour yield, bran score, mill type scores, flour protein content, ash content, Mixograph water absorption (water abs.), Mixograph mixing time (MTime), Mixograph tolerance (MTol), loaf volume, and external appearance (Ext. score), crumb grain score, crumb texture score, and overall baking score as determined by the Wheat Quality Laboratory at the University of Nebraska (Baenziger et al., 2001). All reported values were measured at a $140 \mathrm{~g} \mathrm{H}_{2} \mathrm{O} \mathrm{kg}^{-1}$ flour basis

\begin{tabular}{|c|c|c|c|c|c|c|c|c|c|c|c|c|c|}
\hline \multirow{3}{*}{ Year } & \multicolumn{3}{|c|}{ Milling } & \multirow[b]{2}{*}{$\begin{array}{l}\text { Protein } \\
\text { in flour }\end{array}$} & \multirow[b]{2}{*}{$\begin{array}{l}\text { Flour } \\
\text { ash }\end{array}$} & \multicolumn{3}{|c|}{ Mixograph } & \multicolumn{5}{|c|}{ Baking } \\
\hline & $\begin{array}{l}\text { Flour } \\
\text { yield }\end{array}$ & $\begin{array}{l}\text { Bran } \\
\text { score }\end{array}$ & $\begin{array}{l}\text { Mill type } \\
\text { score }\end{array}$ & & & $\begin{array}{l}\text { Water } \\
\text { abs. }\end{array}$ & MTime & MTol & $\begin{array}{l}\text { Loaf } \\
\text { vol. }\end{array}$ & $\begin{array}{l}\text { Ext. } \\
\text { score }\end{array}$ & $\begin{array}{l}\text { Crumb } \\
\text { grain } \\
\text { score }\end{array}$ & $\begin{array}{l}\text { Crumb } \\
\text { texture } \\
\text { score }\end{array}$ & $\begin{array}{l}\text { Overall } \\
\text { baking } \\
\text { 2score }\end{array}$ \\
\hline & $\mathrm{g} \mathrm{kg}^{-1}$ & 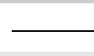 & $1-5^{\mathrm{a}}$ & $\longrightarrow$ & $-\mathrm{g} \mathrm{kg}^{-1}$ & & $\min$ & $0-7^{\mathrm{b}}$ & $\mathrm{L}$ & 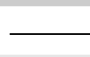 & -0 & $-6^{c}$ & \\
\hline \multicolumn{14}{|c|}{ NE10589 } \\
\hline 2011 & 744 & 4.0 & 3.5 & 112 & 4.60 & 630 & 4.22 & 4.1 & 0.793 & 3.8 & 3.5 & 3.8 & 3.7 \\
\hline 2012 & 717 & 3.5 & 0.5 & 114 & 4.26 & 635 & 5.16 & 4.4 & 0.785 & 3.5 & 3.0 & 3.0 & 3.2 \\
\hline 2013 & 709 & 3.5 & 1.5 & 114 & 4.22 & 625 & 4.30 & 4.7 & 0.916 & 5.0 & 4.4 & 4.5 & 4.6 \\
\hline 2014 & 724 & 3.5 & 2.5 & 125 & 3.96 & 650 & 5.22 & 4.1 & 0.968 & 5.0 & 4.3 & 4.0 & 4.4 \\
\hline Mean & $723 a$ & $3.6 a$ & $2.0 \mathrm{~b}$ & $11.6 \mathrm{~b}$ & $4.26 \mathrm{a}$ & $635 a$ & $4.72 \mathrm{a}$ & $4.30 \mathrm{a}$ & $0.865 \mathrm{a}$ & $4.3 \mathrm{a}$ & $3.8 \mathrm{a}$ & $3.8 \mathrm{~b}$ & $4.0 \mathrm{~b}$ \\
\hline \multicolumn{14}{|c|}{ Wesley } \\
\hline 2011 & 751 & 3.5 & 4.5 & 116 & 4.64 & 635 & 4.01 & 4.6 & 0.835 & 4.3 & 3.4 & 3.6 & 3.8 \\
\hline 2012 & 734 & 4.0 & 4.5 & 123 & 3.86 & 640 & 5.85 & 5.4 & 0.775 & 3.8 & 3.8 & 3.8 & 3.8 \\
\hline 2013 & 708 & 3.5 & 3.5 & 146 & 3.90 & 645 & 4.35 & 4.9 & 0.950 & 5.4 & 4.5 & 5.1 & 5.0 \\
\hline 2014 & 743 & 3.5 & 4.5 & 139 & 3.95 & 680 & 5.31 & 4.9 & 0.968 & 5.0 & 4.8 & 5.0 & 4.9 \\
\hline Mean & $734 a$ & $3.6 \mathrm{a}$ & $4.3 \mathrm{a}$ & $13.1 \mathrm{a}$ & $4.09 \mathrm{a}$ & $650 a$ & $4.88 \mathrm{a}$ & $5.0 \mathrm{a}$ & $0.882 \mathrm{a}$ & $4.6 \mathrm{a}$ & $4.1 \mathrm{a}$ & $4.4 \mathrm{a}$ & $4.4 \mathrm{a}$ \\
\hline \multicolumn{14}{|c|}{ Overland } \\
\hline 2011 & 745 & 3.5 & 4.5 & 103 & 4.46 & 63.5 & 3.52 & 2.8 & 0.788 & 3.3 & 2.3 & 2.3 & 2.6 \\
\hline 2012 & 718 & 3.5 & 4.5 & 116 & 4.48 & 63.0 & 3.18 & 3.9 & 0.790 & 4.0 & 2.8 & 2.5 & 3.1 \\
\hline 2013 & 615 & & & 122 & 4.43 & 64.5 & 2.91 & 2.8 & 0.889 & 4.9 & 3.5 & 3.5 & 4.0 \\
\hline 2014 & 726 & 3.5 & 4.5 & 116 & 3.82 & 63.5 & 4.51 & 4.1 & 0.934 & 4.8 & 3.4 & 3.1 & 3.8 \\
\hline Mean & $701 \mathrm{a}$ & $3.5 \mathrm{a}$ & $4.5 \mathrm{a}$ & $11.4 \mathrm{~b}$ & $4.30 \mathrm{a}$ & $636 a$ & $3.53 \mathrm{~b}$ & $3.40 \mathrm{~b}$ & $0.850 \mathrm{a}$ & $4.2 \mathrm{a}$ & $3.0 \mathrm{~b}$ & $2.8 \mathrm{c}$ & $3.3 c$ \\
\hline
\end{tabular}

Note. Means followed by the same letter are not significantly different at the $p=.05$ level.

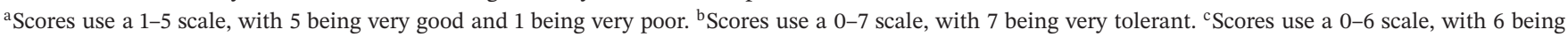
excellent.

loaf volume of NE10589 (0.865 L) was less than that of Wesley $(0.882 \mathrm{~L})$ and better than that of Overland $(0.850$ L). The scores for the internal crumb grain and texture were both 3.8, which were lower than Wesley (4.1 and 4.3, respectively) and better than Overland (3.0 and 2.8, respectively). The overall end-use quality characteristic for NE10589 (scored as 4.0, where 3 is fair, 4.0 is good, and 6.0 is excellent) was less than that of Wesley (4.4) and better than that of Overland (3.3) and similar to many commonly grown wheat cultivars. NE10589 should be acceptable to good to the milling and baking industries.

\subsection{Seed purification and increase}

Seed purification of NE10589 began in 2013 and continued through 2015 using visual identification and manual removal of variants (plants that were taller in height [5-15 cm], were awnless, or had bronze chaff) in bulk seed increases grown under rainfed conditions at Lin- coln and Mead, NE. NE10589 has been uniform and stable since 2013 . Less than $0.5 \%$ of the plants were rogued from the breeder's seed increase in 2010-2013. Up to $1 \%$ (10:1000) variant plants may be encountered in subsequent generations.

\section{4 | AVAILABILITY}

The Nebraska Foundation Seed Division, University of Nebraska, Lincoln, NE, has had foundation seed available under the marketing name Husker Genetics Brand Ruth to qualified certified seed enterprises since 2015. The seed classes are breeder, foundation, registered, and certified. Registered seed will be a nonsalable class. NE10589 is protected by U.S. Plant Variety Protection under P. L. 10577 with the certification option (Certificate no. 201700273). A research and development fee will be assessed on all certified seed sales. Small quantities of seed for research purposes may be obtained from Dr. P. S. Baenziger and 
the Department of Agronomy and Horticulture, University of Nebraska-Lincoln, for at least five years from the date of this release. A seed sample has been deposited in the USDA-ARS National Center for Genetic Resources Preservation and in the USDA-ARS National Small Grains Collection, Aberdeen, ID, and seed is freely available to interested researchers.

\section{ACKNOWLEDGMENTS}

The Nebraska Crop Improvement Association provided technical assistance in describing the cultivar characteristics and accomplishing technology transfer. NE10589 was developed with partial financial support from the Nebraska Agricultural Experiment Station and the Nebraska Wheat Development, Utilization, and Marketing Board. Partial funding for P.S. Baenziger was from Hatch project NEB-22-328; USDA-IFAFS competitive grant 2001-04462; USDA, NRICGP 00-353000-9266, 2004-35300-1470, and 2007-51300-0375; USDA, CSREES NRICAP Grant no. 2006-55606-16629; USDA OREI 200751300-03785, AFRI/2011-68002-30029; the CERES Trust Organic Research Initiative; and USDA under Agreement no. 59-0790-4-092, which was a cooperative project with the U.S. Wheat \& Barley Scab Initiative. Any opinions, findings, conclusions, or recommendations expressed in this publication are those of the authors and do not necessarily reflect the view of the USDA. Mention of trade names or commercial products in this publication is solely for the purpose of providing specific information and does not imply recommendation or endorsement by the U.S. Department of Agriculture. USDA is an equal opportunity provider and employer. Cooperative investigations of the Nebraska Agric. Res. Div., Univ. of Nebraska, and USDA-ARS.

\section{CONFLICT OF INTEREST}

The authors declare no conflict of interest.

\section{O R C I D}

P. S. Baenziger (10 https://orcid.org/0000-0002-9109-6954

M. J. Guttieri (D) https://orcid.org/0000-0002-8099-0686

G. Bai (1) https://orcid.org/0000-0002-1194-319X

R. L. Bowden (10) https://orcid.org/0000-0001-9419-6574

A. Lorenz (1) https://orcid.org/0000-0002-4361-1683

\section{RE F E RE N C ES}

American Association of Cereal Chemists. (2000). Approved methods of the American Association of Cereal Chemists (10th ed.). St. Paul, $\mathrm{MN}$ : AACC International.

Andersen, K., Morris, L., Derksen, R., Madden, L., \& Paul, P. (2014). Rainfastness of prothioconazole tebuconazole for Fusarium head blight and deoxynivalenol management in soft red winter wheat.
Plant Disease, 98, 1398-1406. https://doi.org/10.1094/PDIS-01-140092-RE

Baenziger, P. S., Beecher, B., Graybosch, R. A., Baltensperger, D. D., Nelson, L. A., Krall, J. M., ... Chen, M.-S. (2004). Registration of 'Goodstreak' wheat. Crop Science, 44, 1473-1474. https://doi.org/ 10.2135/cropsci2004.1473

Baenziger, P. S., Beecher, B., Graybosch, R. A., Ibrahim, A. M. H., Baltensperger, D. D., Nelson, L. A., ... Bai, G. (2008). Registration of 'NE01643' wheat. Journal of Plant Registrations, 2, 36-42. https:// doi.org/10.3198/jpr2007.06.0327crc

Baenziger, P. S., Graybosch, R. A., Nelson, L. A., Klein, R. N., Baltensperger, D. D., Xu, L., ... Bai, G. (2009). Registration of 'Camelot' wheat. Journal of Plant Registrations, 3, 256-263. https:// doi.org/10.3198/jpr2009.05.0256crc

Baenziger, P. S., Graybosch, R. A., Nelson, L. A., Regassa, T., Klein, R. N., Baltensperger, D. D., ... Bai, G. (2011). Registration of 'NH03614 CL' wheat. Journal of Plant Registrations, 5, 75-80. https://doi.org/ 10.3198/jpr2010.02.0084crc

Baenziger, P. S., Graybosch, R. A., Regassa, T., Klein, R. N., Kruger, G. R., Santra, D. K., ... Poland, J. (2014). Registration of 'NE06545' (Husker Genetics Brand Freeman) hard red winter wheat. Journal of Plant Registrations, 8, 279-284. https://doi.org/10.3198/jpr2014. $02.0009 \mathrm{crc}$

Baenziger, P. S., Graybosch, R. A., Regassa, T., Klein, R. N., Kruger, G. R., Santra, D. K., ... Poland, J. (2016). Registration of 'NE05548' (Husker Genetics Brand Panhandle) hard red winter wheat. Journal of Plant Registrations, 10, 276-282. https://doi.org/10.3198/ jpr2016.01.0006crc

Baenziger, P. S., Graybosch, R. A., Regassa, T., Nelson, L. A., Klein, R. N., Santra, D. K., ... Bai, G. (2012a). Registration of 'NI04421' hard red winter wheat. Journal of Plant Registrations, 6, 54-59. https:// doi.org/10.3198/jpr2011.02.0102crc

Baenziger, P. S., Graybosch, R. A., Regassa, T., Nelson, L. A., Klein, R. N., Santra, D. K., .. B Bai, G. (2012b). Registration of 'NE01481' hard red winter wheat. Journal of Plant Registrations, 6, 49-53. https:// doi.org/10.3198/jpr2011.02.0101crc

Baenziger, P. S., Moreno-Sevilla, B., Peterson, C. J., Shelton, D. R., Elmore, R. W., Nordquist, P. T., ... Hein, G. (2001). Registration of 'Millennium' wheat. Crop Science, 41, 1367-1369. https://doi.org/ 10.2135/cropsci2001.4141367-ax

Baenziger, P. S., Schmidt, J. W., Peterson, C. J., Johnson, V. A., Mattern, P. J., Dreier, A. F., ... Hatchett, J. H. (1989). Registration of 'Arapahoe' wheat. Crop Science, 29, 832. https://doi.org/10.2135/ cropsci1989.0011183X002900030070x

Baenziger, P. S., Shelton, D. R., Shipman, M. J., \& Graybosch, R. A. (2001). Breeding for end-use quality: Reflections on the Nebraska experience. Euphytica, 119, 95-100. https://doi.org/10. 1023/A:1017583514424

Chen, M. S., Echegaray, E., Whitworth, R. J., Wang, H. Y., Sloderbeck, P. E., Knutson, A., ... Royer, T. A. (2009). Virulence analysis of Hessian fly populations from Texas, Oklahoma, and Kansas. Journal of Economic Entomology, 102, 774-780. https://doi.org/10.1603/ 029.102.0239

El-Basyoni, I., Baenziger, P. S., Dweikat, I., Wang, D., Eskridge, K. M., \& Saadalla, M. (2013). Using DArT markers to monitor genetic diversity throughout selection: A case study in Nebraska's winter wheat breeding nurseries. Crop Science, 53, 23632373. 
Endelman, J. B., \& Jannink, J.-L. (2012). Shrinkage estimation of the realized relationship mattrix. G3: Genes, Genomes, Genetics, 2 , 1405-1413. https://doi.org/10.1534/g3.112.004259

Graybosch, R. A., Baenziger, P. S., Santra, D., Regassa, T., Jin, Y., Kolmer, J., ... Marshall, D. M. (2014). Release of 'Mattern' waxy (amylose-free) winter wheat. Journal of Plant Registrations, 8, 4348. https://doi.org/10.3198/jpr2013.08.0045crc

Hunger, R. M., Armitage, C. R., \& Sherwood, J. L. (1989). Effects of wheat soilborne mosaic virus on hard red winter wheat. Plant Disease, 73, 949-952. https://doi.org/10.1094/PD-73-0949

Kolmer, J. A. (2003). Postulation of leaf rust resistance genes in selected soft red winter wheat cultivars. Crop Science, 43, 12661274. https://doi.org/10.2135/cropsci2003.1266

Peterson, C. J. (1992). Similarities among test sites based on cultivar performance in the hard red winter wheat region. Crop Science, 32, 907-912. https://doi.org/10.2135/cropsci1992. 0011183X003200040014x

Peterson, C. J., Shelton, D. R., Baenziger, P. S., Baltensperger, D. D., Graybosch, R. A., Worrall, W. D., ... Krall, J. (2001). Registration of 'Wesley' wheat. Crop Science, 41, 260-261. https://doi.org/10.2135/ cropsci2001.411260-ax

Rouse, M. N., Wanyera, R., Njau, P., \& Jin, Y. (2011). Sources of resistance to stem rust race Ug99 in spring wheat germplasm. Plant Disease, 95, 762-766. https://doi.org/10.1094/PDIS-12-10-0940

Schmidt, J. W., Johnson, V. A., Mattern, P. J., \& Drier, A. F. (1971). Registration of Scout 66 wheat. Crop Science, 11, 138. https://doi. org/10.2135/cropsci1971.0011183X001100010073x
Sidiqi, J., Wegulo, S. N., Read, P. E., \& Baenziger, P. S. (2009). Frequency of resistance to stem rust race TPMK in Afghan wheat cultivars. Canadian Journal of Plant Pathology, 31, 250-253. https:// doi.org/10.1080/07060660909507598

Stroup, W. W., Baenziger, P. S., \& Mulitze, D. K. (1994). A comparison of methods for removing spatial variation from wheat yield trials. Crop Science, 34, 62-66. https://doi.org/10.2135/cropsci1994. 0011183X003400010011x

Watkins, J. E., Schimelfenig, J., Baenziger, P. S., \& Eskrdige, K. M. (2001). Virulence of Puccinia triticina on wheat in Nebraska during 1997 and 1998. Plant Disease, 85, 159-164. https://doi.org/10.1094/ PDIS.2001.85.2.159

Wegulo, S. N., Backus, W. W., Nopsa, J. H., DeWolf, E. D., Eskridge, K. M., Peiris, K. H. S., \& Dowell, F. E. (2011). Effects of integrating cultivar resistance and fungicide application on Fusarium head blight and deoxynivalenol in winter wheat. Plant Disease, 95, 554-560. https://doi.org/10.1094/PDIS-07-10-0495

How to cite this article: Baenziger PS, Graybosch RA, Rose DJ, et al. Registration of 'NE10589' (Husker Genetics Brand Ruth) hard red winter wheat. J. Plant Regist. 2020;14:388-397.

https://doi.org/10.1002/plr2.20068 